\title{
Bladder carcinogenesis in rats subjected to ureterosigmoidostomy and treated with L-lysine
}

\section{Carcinogênese de bexiga em ratas submetidas à ureterossigmoidostomia tratadas com L-lisina.}

Concelção Aparecida Dornelas'; Alessandra Marques dos Santos²; Antonio lucas Oliveira Correia33; Camila de Carvalho Juanes²;

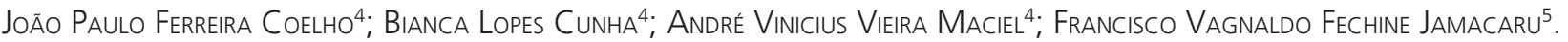

\begin{abstract}
A B S T R A C T
Objective: to evaluate the effect of L-lysine in the bladder and intestinal epithelia in rats submitted to vesicosigmoidostomy. Methods: we divided forty Wistar rats into four groups: group I - control group (Sham); group II - submitted to vesicosigmoidostomy and treated with L-lysine $150 \mathrm{mg} / \mathrm{kg}$; group III - submitted only to vesicosigmoidostomy; and group IV - received L-lysine $150 \mathrm{mg} / \mathrm{kg}$. After eight weeks the animals were sacrificed. Results: in the bladders of all operated animals we observed simple, papillary and nodular hyperplasia of transitional cells, transitional cell papillomas and squamous metaplasia. As for the occurrence of aberrant crypt foci in the colons of operated animals, we did not observe statistically significant differences in any of the distal, proximal and medium fragments, or in all fragments together $(p=1.0000)$. Conclusion: Although statistically there was no promotion of carcinogenesis in the epithelia of rats treated with L-lysine in the observed time, it was clear the histogenesis of bladder carcinogenesis in its initial phase in all operated rats, this being probably associated with chronic infection and tiny bladder stones.
\end{abstract}

Keywords: Lysine. Carcinogenesis. Urinary Bladder Neoplasms. Epithelium. Therapeutics.

\section{INTRODUCTION}

$H^{2}$ ammer described the first case of carcinoma in ureterosigmoidostomy in $1929^{1}$. The risk of cancer in anastomoses areas or bowel of patients undergoing surgery for urinary derivations, bladder expansions or bladder replacements with intestinal segments is known for a long time. Most are adenocarcinomas, but transitional cell carcinomas have also been described. Although the lag time between urinary bypass surgery and the onset of cancer is long, the risk of cancer after ureterosigmoidostomy is estimated at 200 to 500 times compared with the general population. However, the exact pathophysiology of this carcinogenesis process is not known. The earliest pre-neoplastic lesions in colorectal carcinogenesis are the dysplastic aberrant crypts foci (ACF), mucin depleted foci (MDF) and b-catenin-acumulated crypts $(B C A C)^{2}$. Dornelas et al. ${ }^{3}$ found that $L$-ly- sine has promotes bladder chemical carcinogenesis in rats. The objective of this study is to evaluate the effect of this amino acid in the bladder and intestinal epithelia of animals undergoing urinary diversion by vesicosigmoidostomy, a classic experimental surgical carcinogenesis model ${ }^{4}$.

\section{METHODS}

The research project was conducted at the Department of Pathology and Forensic Medicine of Faculty of Medicine of the Universidade Federal do Ceará (UFC) and developed according to the protocol approved by the Ethics in Animal Research Committee (CEPA) of the Universidade Federal do Ceará.

We divided 40 Wistar rats weighing 150 grams into four groups: Group I (6 animals) was submitted to the opening and closing of the lateral walls of rectum and bladder; Group II (14 mice) was

1. Departamento de Patologia e Medicina Legal da Faculdade de Medicina da Universidade Federal do Ceará - UFC, Fortaleza/CE, Brasil; 2. Programa de Pós-Graduação em Patologia da Faculdade de Medicina da Universidade Federal do Ceará - UFC, Fortaleza/CE, Brasil; 3. Serviço de Oftalmologia do Hospital Geral de Fortaleza, Fortaleza/CE, Brasil; 4. Faculdade de Medicina da Universidade Federal do Ceará - UFC, Fortaleza/CE, Brasil; 5. Departamento de Fisiologia e Farmacologia da Faculdade de Medicina da Universidade Federal do Ceará - UFC, Fortaleza/CE, Brasil. 


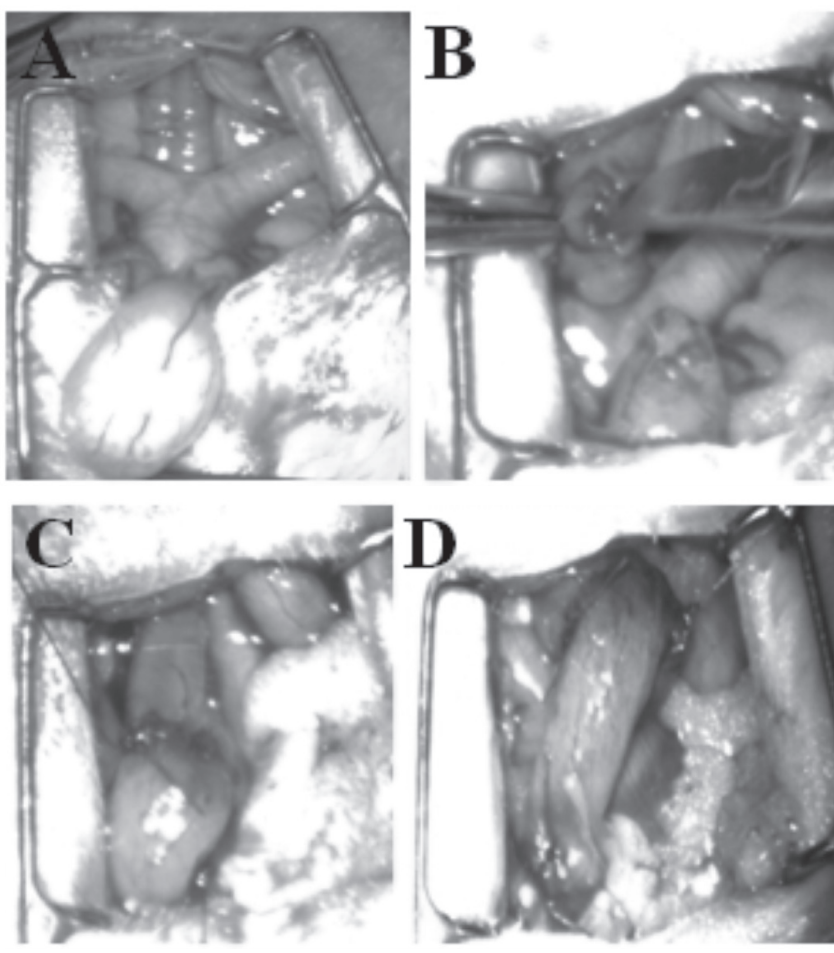

Figure 1. Surgical steps of vesicosigmoidostomy by the Crissey 1980 technique: A) Bladder exposure, bicornuate uterus and cervix; B) bladder dome opening and longitudinal incision of colon wall; C) 7-0 Vycril continuous running suture of bladder dome to the colon; and D) suture of bladder neck and urethral section.

subjected to vesicosigmoidostomy according to the Crissey technique ${ }^{4}$ (Figure 1), and subsequently treated with L-lysine $150 \mathrm{mg} / \mathrm{kg}$ diluted in $0.5 \mathrm{ml}$ distilled water by gavage; Group III (14 animals) was submitted only to vesicosigmoidostomy; Group IV received only L-lysine $150 \mathrm{mg} / \mathrm{kg}$ diluted in $0.5 \mathrm{ml}$ distilled water by gavage. After eight weeks we sacrificed the animals and carried out histological analysis (haematoxylin and eosin) of specimens from the the areas of rectal and bladder anastomosis; The colons was fixed and then stained with $0.1 \%$ methylene blue for evaluation of aberrant crypt foci in stereomicroscopy ${ }^{5,6}$.

\section{RESULTS}

In all operated animals we macroscopically observed polypoid lesions located in the anastomoses regions and bladder epithelium. There were numerous tiny calculi inside the bladders of individuals submitted to vesicosigmoidostomy. In one animal, there was dilation of the right ureter and faceted calculi therein, forming a Stone Street (Figure 2).
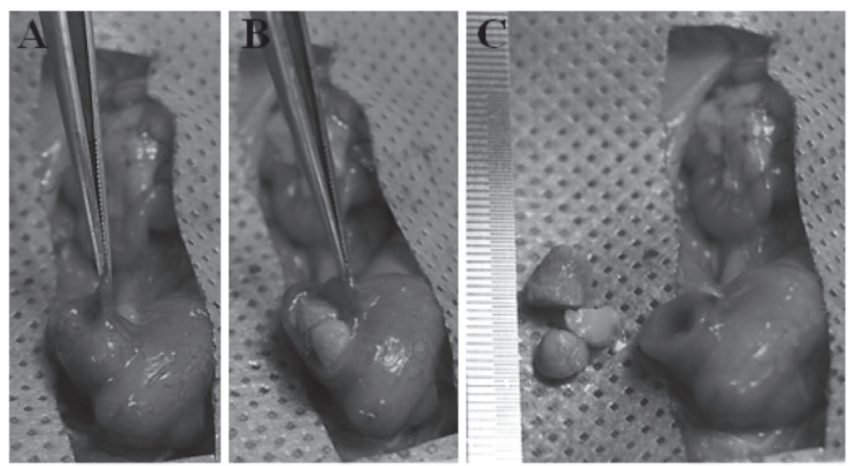

Figure 2. A) dilated ureter in its near-bladder segment; B) opening of the ureter, displaying the stone street within; C) several multifaceted calculi, the biggest measuring $5 \mathrm{~mm}$.

On histopathology, the bladder segment of all the operated animals displayed transitional cells simple, nodular and papillary hyperplasia, transitional cell papilloma, (Figure 3) and transitional cell papilloma with squamous metaplasia. In the intestinal segment in operated rats, there were rare aberrant crypts and foci of chronic colitis near the anastomosis area, and some animals presented with atrophy of the epithelium with mucin reduction in areas distant from the anastomosis.

Mortality among operated animals was $45 \%$ (18 animals). The main causes were kidney and lung abscesses.

Except by group IV, in all other groups, even in the one in which the animals were not operated, the stereoscopic microscopy identified rare ACF. All ACF contained only one crypt. There were no multiplicity of crypts or dysplasia signs in the ACF.

As for the occurrence of ACF in stereoscopic evaluation, when comparing Groups II and III (operated animals) with the Fisher's exact test, we did not find statistically significant differences considering the proximal $(p=1.0000)$, medium $(p=1.0000)$ and distal $(p=1.0000)$ fragments, or all fragments together $(p=1.0000)$ (Table 1).

Regarding the presence or absence of aberrant crypts, the data were expressed as median, interquartile range and minimum and maximum values of measurements made in five animals of Groups I and IV and six rats in Groups II and III. We used the Kruskal-Wallis test to compare the four groups, associated with the multiple comparison test of Dunn, to check for differences between groups in pairs. The 


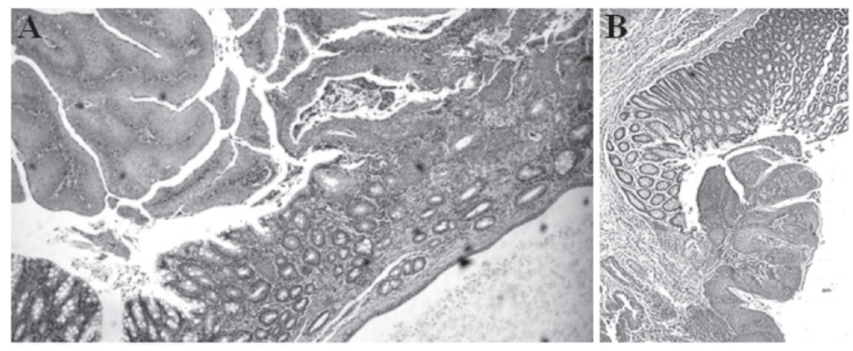

Figure 3. A) histologic section showing colovesical anastomosis with transitional cell papilloma; and B) transitional cell papillary hyperplasia with squamous metaplasia. Hematoxylin and eo$\sin 10 x$ increase.

results of the evaluation of the number of aberrant crypts found in the proximal, middle and distal colon segments are described in table 2 and in figure 4.

\section{DISCUSSION}

The carcinogenesis of anastomoses in urinary derivations with gastrointestinal segments remains unclear. Some mechanisms have been proposed to explain the pathophysiology, such as chronic inflammation, recurrent infections, hydrogenionic potential changes $(\mathrm{PH})$ and production of carcinogens by bacteria, among other causes ${ }^{7}$. The first urinary diversion was the ureterosigmoidostomy, followed years later by colocystoplasty, ileocystoplasty and gatrocystoplasty. Then, there was the appearance of malignancy in a higher percentage than in the general population in the different derivations and urinary bladder enlargements with gastrointestinal segments. Some authors postulated that patients under 25 years of age undergoing ureterosigmoidostomy had 7,000 times greater risk for developing cancer than the same age population ${ }^{8}$.

Many experimental studies were performed in rats using the Crissey vesicosigmoidostomy model ${ }^{4}$,

Table 1. Occurrence of aberrant crypt foci in groups II and III considering the proximal, middle and distal segments.

\begin{tabular}{lccc}
\hline Segments & \multicolumn{2}{c}{ Aberrant Crypt Foci } & $\begin{array}{c}\text { Significance } \\
\text { (Fisher's exact } \\
\text { test) }\end{array}$ \\
& $\begin{array}{c}\text { Group II } \\
\mathrm{n} / \mathrm{N}(\%)\end{array}$ & $\begin{array}{c}\text { Group III } \\
\mathrm{n} / \mathrm{N}(\%)\end{array}$ & \\
\hline Proximal & $3 / 6(50)$ & $2 / 6(33,33)$ & $\mathrm{P}=1,0000$ \\
Middle & $1 / 6(16,67)$ & $0 / 6(0,00)$ & $\mathrm{P}=1,0000$ \\
Distal & $0 / 6(0,00)$ & $1 / 6(16,67)$ & $\mathrm{P}=1,0000$ \\
All segments & $4 / 6(66,67)$ & $3 / 6(50)$ & $\mathrm{P}=1,0000$ \\
\hline
\end{tabular}

$n$ : number of rats with aberrant crypt foci in the group; $N$ : number of animals in the group. searching for histopathologic changes, without using carcinogens, and identifying chronic inflammation, hyperplasia and dysplasia with sulfomucins reduction and increased sialomucins ${ }^{9}$. Gitlin et al. ${ }^{7}$ held gastrocystoplasty and ileocystoplasty in dogs and observed overgrowth of transitional epithelium in enterovesical and gastrovesical anastomoses. These cells expressed not only uroplakins (a molecular marker for urothelial differentiation), but also mucosubstance. They then suggested that these anastomotic cells possessed alterations and hybrid characteristics, possibly being vulnerable to neoplastic transformation.

In 2012, in a study of 44 different centers between 1970 and 2007 with 17,758 patients undergoing urinary derivations and bladder plasty with intestinal loops, German researchers found 32 tumors $^{10}$. The risk of tumors in ureterosigmoidostomy was 22 times higher, and in cystoplasty, 13 times higher, than in other forms of continent urinary diversion, such as neobladder, with statistical significance $(p<0.0001)$. The risk of tumors in ileocecal derivations $(1.26 \%)$ and in colon derivation with neobladder was $1.43 \%$, significantly higher $(p=0.0001)$ than in ileal neobladder $(0.5 \%)^{10}$.

Our approach for evaluation of colorectal carcinogenesis was the research of aberrant crypts foci (ACF). The ACF was originally described by Bird ${ }^{5}$ in rats subjected to chemical carcinogenesis of the colon. However, some years later the same author suggested, and others have concluded that, the focus of aberrant crypts is in fact part of the sequential evolution of colon carcinogenesis, which can become dysplastic and may cause adenomas and later carcinomas, thus serving as a model of early, or pre-neoplastic, lesion in colorectal carcinogenesis ${ }^{11-13}$. The dysplastic ACF may present microsatellite instability, methylation with epigenetic silencing ${ }^{14}$. For this reason, it has been consecrated as a model for trials of new anticancer molecules, using the model in rats subjected to chemical carcinogenesis ${ }^{13,15}$.

Do urinary derivations follow the course of this aberrant crypt foci model? The answer could be interesting if ACF research could be used in the preventive clinical evaluation of patients undergoing urinary derivations. Does ACF occur in vesicosigmoidostomy in rats? There are no reports in the literature. And fur- 

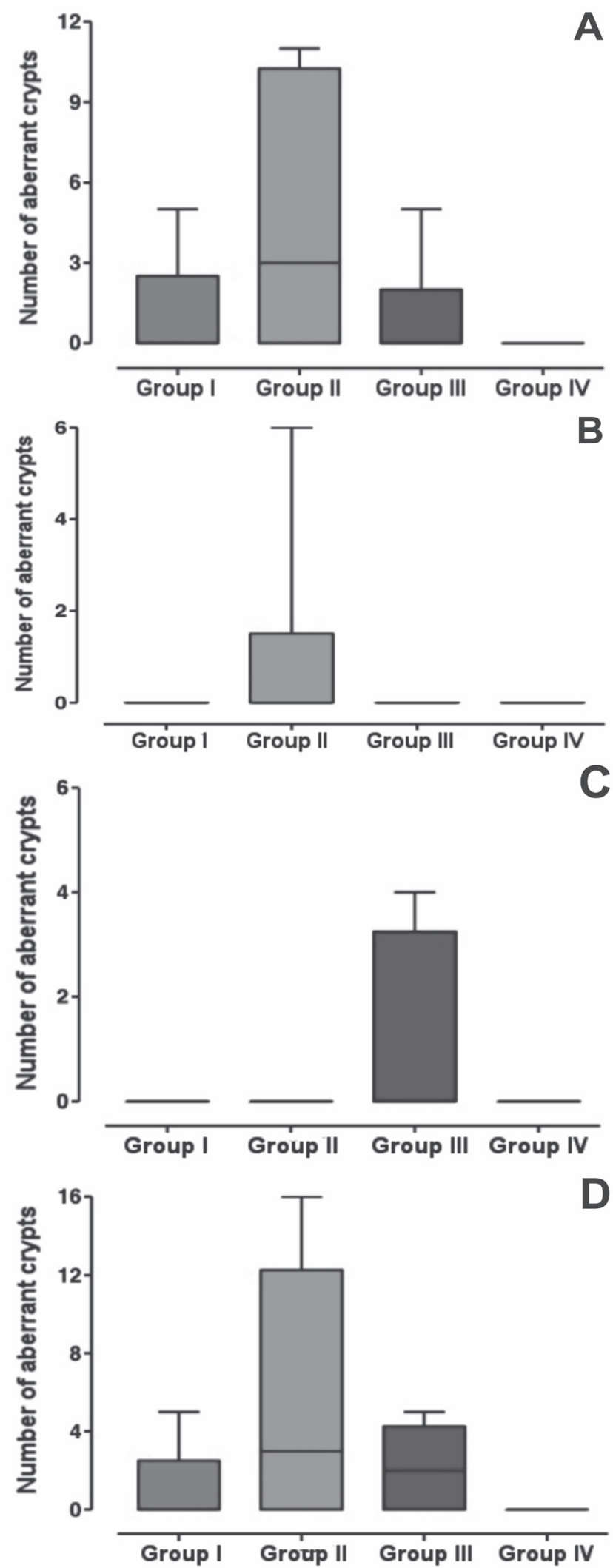

Figure 4. A) Number of Aberrant Crypts observed in the proximal fragments of groups I, II, III and IV; B) Number of Aberrant Crypts observed in the middle fragments of groups I, II, III and $N ; C$ ) Number of Aberrant Crypts observed in the distal fragments of groups I, II, III and I; D) Number of Aberrant Crypts found in groups I, II, III and IV, considering all fragments: proximal, middle and distal. ther, can L-lysine promote carcinogenesis of the colon and/or bladder submitted to urinary diversion in rats? This occurrence is carried out by promoters in primed cells. Promoters are able to take primed cells to proliferation and, therefore, develop additional mutations. Promoters are not capable of producing mutation, but the condition of maintaining cell proliferation is required so that they can contribute to carcinogenesis ${ }^{16}$. In a recent study, Dornelas et al. $^{3}$ found that $L$-lysine has promoting action of bladder carcinogenesis in rats subjected to chemical carcinogenesis by BBN.

In our study we observed rare ACF. There were no multiplicities of aberrant crypts. All ACF contained only one crypt and there were no dysplasias in the ACF. Furthermore, despite a greater number of $a b$ errant crypts in rats submitted to vesicosigmoidostomy, there was no statistically significant difference between groups II and III, so there was no promotion of carcinogenesis in rats treated with L-lysine. In addition, we observed ACF in non-operated animals. Although the significance of finding isolated ACF without dysplasias is still unknown, there are reports of ACF involution. There has also been described the spontaneous emergence of ACF in 344 Fisher rats without the use of a carcinogens $^{17,18}$. The commercial diet can promote ACF induction in modified animals ${ }^{19}$. We should note that the observation time in our experiment was eight weeks. Some authors found that advanced age can influence the spontaneous appearance of ACF in humans ${ }^{20}$.

When analyzing the graph showing the presence of ACF in the proximal (Figure 4A) segment and in proximal, middle and distal segments together (Figure 4D), we noted that there are greater numbers of ACF in animals undergoing surgery and treated with L-lysine than in those who were only operated without L-lysine treatment. However, there was no statistically significant difference.

The bladder segment, on the other hand, proved extremely reactive when subjected to derivation. All operated animals showed histological lesions in the bladder epithelium of transitional cell simple, papillary and nodular hyperplasia, transitional cells papilloma and squamous metaplasia, lesions already described as sequential in the bladder histogenesis/ carcinogenesis in rodents ${ }^{21}$. 
Table 2. Number of Aberrant crypt foci found in all segments in groups I, II, III and IV.

\begin{tabular}{|c|c|c|c|c|c|}
\hline Segments & $\begin{array}{c}\text { Group I } \\
\text { Median } \\
\text { (Interquartile Range) }\end{array}$ & $\begin{array}{c}\text { Group II } \\
\text { Median } \\
\text { (Interquartile Range) }\end{array}$ & $\begin{array}{c}\text { Group III } \\
\text { Median } \\
\text { (Interquartile Range) }\end{array}$ & $\begin{array}{c}\text { Group IV } \\
\text { Median } \\
\text { (Interquartile Range) }\end{array}$ & $\begin{array}{c}\text { Significance } \\
\text { (Kruskal-Wallis) }\end{array}$ \\
\hline Proximal & $\begin{array}{c}0,0 \\
(0,00-2,50)\end{array}$ & $\begin{array}{c}3,0 \\
(0,00-10,25)\end{array}$ & $\begin{array}{c}0,0 \\
(0,00-2,00)\end{array}$ & $\begin{array}{c}0,0 \\
(0,00-0,00)\end{array}$ & $\mathrm{P}=0,2242$ \\
\hline Middle & $\begin{array}{c}0,0 \\
(0,00-0,00)\end{array}$ & $\begin{array}{c}0,0 \\
(0,00-1,50)\end{array}$ & $\begin{array}{c}0,0 \\
(0,00-0,00)\end{array}$ & $\begin{array}{c}0,0 \\
(0,00-0,00)\end{array}$ & $P=0,4459$ \\
\hline Distal & $\begin{array}{c}0,0 \\
(0,00-0,00)\end{array}$ & $\begin{array}{c}0,0 \\
(0,00-0,00)\end{array}$ & $\begin{array}{c}0,0 \\
(0,00-3,25)\end{array}$ & $\begin{array}{c}0,0 \\
(0,00-0,00)\end{array}$ & $P=0,1335$ \\
\hline $\begin{array}{l}\text { All } \\
\text { segments }\end{array}$ & $\begin{array}{c}0,0 \\
(0,00-2,50)\end{array}$ & $\begin{array}{c}3,0 \\
(0,00-12,25)\end{array}$ & $\begin{array}{c}0,0 \\
(0,00-4,25)\end{array}$ & $\begin{array}{c}0,0 \\
(0,00-0,00)\end{array}$ & $P=0,1477$ \\
\hline
\end{tabular}

Calcium salts precipitate at high $\mathrm{pH}$ and urate salts precipitate at low $\mathrm{pH}$. In humans, urolithiasis is very common, but the association between calculi and bladder cancer is rare. However, in rats and mice, crystals and urolithiasis increase the likelihood of bladder carcinogenesis 22,23 .

When the bladder epithelium is subjected to mechanical irritative processes (calculi, foreign body) and recurrent infection, it can evolve into reactive histologic lesions and also sequentially to carcinogenesis in humans.

The bladder epithelium is similar among species. However, there are anatomical differences that may pathophysiologically explain the association between calculi and carcinogenesis in animals. During voiding, the urinary system of rodents is in horizontal position, whilst the human is in vertical one. When the bladder contracts, it all "wrinkles" except by the trigone region. When there are stones in the bladder of rats, these loose crystals in the anterior wall promote mucosal damage throughout the bladder with contraction. In humans, foreign objects are located in the trigone region, which does not contract during urination. Mucosal damage is then decreased. For this same anatomical reason, human quickly eliminate the crystals that are within the bladder. When calculi cause obstruction in humans, they cause pain in most cases, what makes treatment and desobstruction to be arranged. Thus, anatomical factors can make rodents more susceptible to bladder carcinogenesis ${ }^{23,24}$.

Our animals did not have a functioning bladder trigone. We ligated the bladder neck and sectioned it, but the bladder was still kept in the horizontal position and saccular, not eliminating the bladder contents through the rectum. This occurred in all operated animals of our experiment in a similar way (groups II and III). Urine, feces, repeated infections may have originated the miniature calculi and the histological lesions. All animals presented with miniature calculi in the bladder, and once the bladder of the animal is positioned ventrally due to four-paw ambulation, the irritating stimulus keeps constant and may explain the magnitude of the histological changes observed in bladder epithelium.

In conclusion, although statistically there was no promotion of carcinogenesis in the epithelia of rats treated with $L$-lysine in the observed time, the histogenesis of bladder carcinogenesis is clear in its initial phase in the bladder epithelium in all operated rats, this being probably associated with chronic infection and tiny bladder stones.

\section{A B S T R A C T}

Objetivo: o objetivo deste trabalho é avaliar o efeito da L-lisina nos epitélios vesical e intestinal de ratas submetidas à vesicossigmoid-
ostomia. Métodos: quarenta ratas Wistar, foram divididas em quatro grupos: grupo I- grupo controle (Sham); grupo II- submetido à
vesicossigmoidostomia e tratado com L-lisina 150mg/kg; grupo III- submetido apenas à vesicossigmoidostomia; e grupo IV-recebeu L-lisina
150mg/kg. Após oito semanas os animais foram sacrificados. Resultados: na bexiga de todos os animais operados observou-se hiperplasia
simples, papilar e nodular de células transicionais, papiloma de células transicionais e metaplasia escamosa. Quanto à ocorrência de focos
de criptas aberrantes nos colos dos animais operados, não foi evidenciado diferença estatística significante em nenhum dos fragmentos
distal, proximal e médio, e todos juntos (P=1,0000). Conclusão: apesar de, estatisticamente, não ter havido promoção de carcinogênese
nos epitélios dos ratos tratados com L-lisina, no tempo observado, é nítida a histogênese da carcinogênese de bexiga em sua fase inicial,
no epitélio vesical, em todos os ratos operados, estando esta provavelmente associada à infecção crônica e aos diminutos cálculos vesicais.

Descritores: Lisina. Carcinogênese. Neoplasias da Bexiga Urinária. Epitélio. Terapêutica. 


\section{REFERENCES}

1. Hammer E. Cancer du colon sigmoide dix ans après implantation des uretères d'une vessie exstrophiée. J Urol. 1929;28:260.

2. Femia AP, Paulsen JE, Dolara P, Alexander J, Caderni $G$. Correspondence between flat aberrant crypt foci and mucin-depleted foci in rodent colon carcinogenesis. Anticancer Res. 2008;28(6A):3771-5.

3. Dornelas CA, Fechine-Jamacaru FV, Albuquerque IL, Magalhães HIF, Souza AJS, Alves LA, et al. Chemoprevention with green propolis extracted in L-lysine versus carcinogenesis promotion with L-lysine in N-butyl-N-[4-hydroxybutyl] nitrosamine (BBN) induced rat bladder cancer. Acta Cir Bras. 2012;27:(2);185-92.

4. Crissey MM, Steele GD, Gittes RF. Rat model for carcinogenesis in ureterosigmoidostomy. Science. 1980;207(4435):1079-80.

5. Bird RP. Observations and quantification of aberrant crypts in the murine colon treated with a coIon carcinogen: preliminary findings. Cancer Lett. 1987;37(2):147-51.

6. Burlamaqui IMB, Dornelas CA, Escalante RD, Mota DMC, Mesquita FJC, Carvalho ER, et al. Optimization of visibility and quantification of aberrant crypt foci in colonic mucosa in Wistar rats. Acta Cir Bras. 2010;25(2):148-52.

7. Gitlin JS, Wu XR, Sun TT, Ritchey ML, Shapiro E. New concepts of histological changes in experimental augmentation cystoplasty: insights into the development of neoplastic transformation at the enterovesical and gastrovesical anastomosis. J Urol. 1999;162(3 Pt 2):1096-100.

8. Eraklis AJ, Folkman MJ. Adenocarcinoma at the site of ureterosigmoidostomies for exstrophy of the bladder. J Pediatr Surg. 1978;13(6D):730-4.

9. Castro MA, Ferreira U, Martins MH, Stoppiglia RM, Rodrigues Netto Jr N. Histological and histochemical changes of the intestinal mucosa at the urothelial-enteric anastomotic site. Int braz j urol. 2006;32(2):222-7.

10. Kälble T, Hofmann I, Thüroff JW, Stein R, Hautmann $\mathrm{R}$, Riedmiller $\mathrm{H}$, et al. Secondary malignancies in urinary diversions. Urologe A. 2012;51(4):500, 502-6.
11. McLellan EA, Medline A, Bird RP. Sequential analyses of the growth and morphological characteristics of aberrant crypt foci: putative preneoplastic lesions. Cancer Res. 1991;51(19):5270-4.

12. Hurlstone DP, Cross SS. Role of aberrant crypt foci detected using high-magnification-chromoscopic colonoscopy in human colorectal carcinogenesis. J Gastroenterol Hepatol. 2005;20(2):173-81.

13. Alrawi SJ, Schiff M, Carroll RE, Dayton M, Gibbs JF, Kulavlat $M$, et al. Aberrant crypt foci. Anticancer Res. 2006;26(1A):107-19.

14. Orlando FA, Tan D, Baltodano JD, Khoury T, Gibbs JF, Hassid VJ, et al. Aberrant crypt foci as precursors in colorectal cancer progression. J Surg Oncol. 2008;98(3):207-13.

15. Burlamaqui IMB, Dornelas $C A$, Valença Júnior JT, Mota DMC, Mesquita FJC, Veras LB, et al. Effect of a hyperlipidic diet rich in omegas 3, 6 and 9 on aberrant crypt formation in rat colonic mucosa. Acta Cir Bras. 2012;27(1):30-6.

16. Pitot HC. The molecular biology of carcinogenesis. Cancer. 1993;72(3 Suppl):962-70.

17. Furukawa F, Nishikawa A, Kitahori Y, Tanakamaru $Z$, Hirose M. Spontaneous development of aberrant crypt foci in F344 rats. J Exp Clin Cancer Res. 2002;21(2):197-201.

18. Tanakamaru Z, Mori I, Nishikawa A, Furukawa F, Takahashi M, Mori H. Essential similarities between spontaneous and MelQx-promoted aberrant crypt foci in the F344 rat colon. Cancer Lett. 2001;172(2):143-9.

19. Svendsen C, Alexander J, Paulsen JE, Knutsen HK, Hjertholm H, Brantsæter AL, et al. The impact of commercial rodent diets on the induction of tumours and flat aberrant crypt foci in the intestine of multiple intestinal neoplasia mice. Lab Anim. 2012;46(3):207-14.

20. Rudolph RE, Dominitz JA, Lampe JW, Levy L, Qu $P$, Li SS, et al. Risk factors for colorectal cancer in relation to number and size of aberrant crypt foci in humans. Cancer Epidemiol Biomarkers Prev. 2005; 14(3):605-8.

21. Oyasu R. Epithelial tumours of the lower urinary tract in humans and rodents. Food Chem Toxicol. 1995;33(9):747-55. 
22. Cohen SM. Role of urinary physiology and chemistry in bladder carcinogenesis. Food Chem Toxicol. 1995;33(9):715-30.

23. Urinary bladder carcinogenesis: implications for risk assessment. Rodent Bladder Carcinogenesis Working Group. Food Chem Toxicol.1995;33(9):797-802.

24. DeSesso JM. Anatomical relationships of urinary bladders compared: their potential role in the development of bladder tumours in humans and rats. Food Chem Toxicol. 1995;33(9):705-14.
Received: 08/10/2015

Accepted for publication: 16/03/2016 Conflict of interest: none.

Source of funding: none.

\section{Mailing address:}

Conceição Aparecida Dornelas

E-mail: eusoucondor@yahoo.com.br 